\title{
COMPARISON OF THE METHANE OXIDATION RATE IN FOUR MEDIA(1)
}

\author{
Juliana Lundgren Rose ${ }^{(2)}$, Cláudio Fernando Mahler ${ }^{(2)} \&$ Ronaldo Luis \\ dos Santos Izzo ${ }^{(3)}$
}

\begin{abstract}
Landfill gas emissions are one of the main sources of anthropogenic methane $\left(\mathrm{CH}_{4}\right)$, a major greenhouse gas. In this paper, an economically attractive alternative to minimize greenhouse gas emissions from municipal solid waste landfills was sought. This alternative consists in special biofilters as landfill covers with oxidative capacity in the presence of $\mathrm{CH}_{4}$. To improve the quality/ cost ratio of the project, compost was chosen as one of the cover substrates and soil (Typic red yellow-silt-clay Podzolic) as the other. The performance of four substrates was studied in laboratory experiments: municipal solid waste (MSW) compost, soil, and two soil-compost at different proportions. This study aimed to evaluate the suitability and environmental compatibility as a means of $\mathrm{CH}_{4}$ oxidation in biofilters. Four biofilters were constructed in $60 \mathrm{~cm}$ PVC tubes with an internal diameter of $10 \mathrm{~cm}$. Each filter contained $2.3 \mathrm{~L}$ of oxidizing substrate at the beginning of the experiment. The gas used was a mixture of $\mathrm{CH}_{4}$ and air introduced at the bottom of each biofilter, at a flow of $150 \mathrm{~mL} \mathrm{~min}-1$, by a flow meter. One hundred days after the beginning of the experiment, the best biofilter was the MSW compost with an oxidation rate of $990 \mathrm{~g} \mathrm{~m}^{-3} \mathrm{day}^{-1}$, corresponding to an efficiency of $44 \%$. It can be concluded that the four substrates studied have satisfactory oxidative capacity, and the substrates can be used advantageously as cover substrate of MSW landfills.
\end{abstract}

Index terms: Methane oxidation, biofilter, municipal solid waste compost, solid waste landfill cover, case study.

(1) Part of the doctoral thesis of first author submitted to the Federal University of Rio de Janeiro (UFRJ). Research financed by CNPq, CAPES e FAPERJ. Received for publication in April 26, 2010 and approved in February 14, 2012.

(2) Associate Professor III, Coordinator GETRES, Waste Management Study Group, PEC-COPPE/UFRJ, Federal University of Rio de Janeiro, Cx. Postal 68506, CEP 21945-970 Rio de Janeiro (RJ), Brazil. www.getres.ufrj.br E-mails: cfmahler@acd.ufrj.br; julrose@gmail.com

(3) Adjunto Professor I, UTFPR, Federal Technological University of Paraná. Rua Deputado Heitor Alencar Furtado, 4900 - Ecoville ZIP COD 81280-340 Curitiba (PR), Brazil. E-mail: izzo@utfpr.edu.br 


\title{
RESUMO: COMPARAÇÃO ENTRE AS TAXAS DE OXIDAÇÃO DE $\mathrm{CH}_{4} E M$ QUATRO DIFERENTES MEIOS
}

\begin{abstract}
Emissões gasosas de aterros de resíduos estão entre as maiores fontes antrópicas de metano $\left(\mathrm{CH}_{4}\right)$, um dos principais gases de efeito estufa. Buscou-se neste trabalho estudar uma alternativa econômica de minimizar a emissão desses gases em aterros de resíduos sólidos urbanos. Essa alternativa compreende o uso de coberturas de aterros com capacidades oxirredutoras especiais na presença de $\mathrm{CH}_{4}$. Ainda visando melhorar a relação qualidade/custo do empreendimento, escolheu-se o composto como um dos materiais a serem empregados na cobertura. O outro material é um solo (Argissolo VermelhoAmarelo silte-argiloso). Para isso, estudou-se em laboratório o comportamento de quatro cenários: composto de resíduo sólido urbano (RSU), solo e duas misturas, em diferentes proporções, de composto e solo. Objetivou-se avaliar a sua adequação e compatibilidade ambiental como meio oxidante de $\mathrm{CH}_{4}$ em biofiltros. Quatro biofiltros de $60 \mathrm{~cm}$ de altura foram construídos em tubos de PVC com diâmetro interno de $10 \mathrm{~cm}$. Cada filtro continha 2,3 L de material oxidante, no início do experimento. O gás empregado foi uma mistura de $\mathrm{CH}_{4}$ e ar, a qual foi introduzida pela parte de baixo de cada biofiltro; o fluxo de gás foi ajustado para $150 \mathrm{~mL} \mathrm{~min}^{-1}$, por rotâmetro. Cem dias após o início do experimento, o biofiltro que apresentou os melhores resultados foi o composto de RSU, com taxa de oxidação de $990 \mathrm{~g} \mathrm{~m}^{-3} \mathrm{dia}^{-1}$, correspondendo a uma eficiencia de $44 \%$. Pode-se concluir que os quatro substratos estudados têm capacidade oxidativa satisfatória, podendo ser utilizados de forma vantajosa como material de cobertura do aterro de resíduos sólidos urbanos.
\end{abstract}

Termos de indexação: oxidação de metano, biofiltro, composto de resíduo sólido urbano, cobertura de aterro de resíduos sólidos, estudo de caso.

\section{INTRODUCTION}

The greenhouse effect is a natural process that heats the planet surface due to the presence of gases contained in the atmosphere that absorb and emit infrared radiation. The main greenhouse gases in the Earth's atmosphere are water vapor, carbon dioxide $\left(\mathrm{CO}_{2}\right)$, methane $\left(\mathrm{CH}_{4}\right)$, nitrous oxide $\left(\mathrm{N}_{2} \mathrm{O}\right)$, and ozone $\left(\mathrm{O}_{3}\right)$. Human activities generate emissions of four long-lived GHGs: $\mathrm{CO}_{2}, \mathrm{CH}_{4}$, $\mathrm{N}_{2} \mathrm{O}$, and halocarbons (a group of gases containing fluorine, chlorine or bromine). The greenhouse effect is dangerous when emissions are higher than the removed quantities, because atmospheric concentrations of GHGs increase and environmental damage could occur.

Methane is the main hydrocarbon present in the atmosphere and one of the principal greenhouse gases. Its atmospheric concentration has significantly increased over the past few hundred years, particularly after the industrial revolution, but growth rates have declined since the early 1990s. The total emission (sum of anthropogenic and natural sources) has been nearly constant since then.

Methane $\left(\mathrm{CH}_{4}\right)$ is emitted from a variety of both human-related and natural sources. Humanrelated activities include fossil fuel production, animal husbandry (enteric fermentation in livestock and manure management), rice cultivation, biomass burning and waste disposal. Natural sources of methane include wetlands, gas hydrates, permafrost, termites, oceans, freshwater bodies, non-wetland soils, and other sources such as wildfires.

Landfills are considered to be an important global source of this greenhouse gas. The amount of methane generated by a landfill depends on the quantity and moisture content of the waste, along with its shape and management.

Since the $\mathrm{CH}_{4}$ generated by landfills is anthropogenic, it is theoretically possible to control it. A significant amount of these emissions could be reduced by applying available and economically feasible options such as capturing the methane and recovering the cost of the emission-reduction technology by selling the gas or using it to replace other energy inputs.

The remaining methane could be oxidized in the landfill cover. $\mathrm{CH}_{4}$ oxidation with biological systems is an approach that is being studied by an increasing number of research groups around the world (Boeckx et al., 1996; De Visscher et al., 1999; Berger et al., 2005; Albanna et al., 2007).

$\mathrm{CH}_{4}$ oxidation in the soil cover of landfills has been reported to be effective in reducing $\mathrm{CH}_{4}$ emissions, since landfill cover soil can contain various groups of microorganisms that are capable of oxidizing $\mathrm{CH}_{4}$, such as methanotrophic bacteria (Whalen et al., 1990; Hanson \& Hanson 1996). 
These bacteria consume $\mathrm{CH}_{4}$ and oxidize it to $\mathrm{CO}_{2}$ and water, producing energy, by the $\mathrm{CH}_{4}$ monooxygenase enzyme of methanotrophic bacteria. The $\mathrm{CH}_{4}$ oxidation rate differs within and between landfill sites, due to the $\mathrm{CH}_{4}$ concentration and characteristics of the soil cover, and also depends on different environmental factors, including moisture and temperature.

Normally, clay soils are used as cover substrates, but many other substrates could be used as an alternative for clay substrates as landfill cover. "Alternative cover" is defined as a cover substrate other than earthen substrate distributed on the surface of a solid waste landfill to control disease vectors, fires, odors, blowing litter, and scavenging. This use should be adjusted to the site-specific characteristics and applicable government rules and regulations. Moreover, alternative substrates for landfill covers should be chosen based on economic analysis and must protect human health and environmental quality under the site-specific conditions, with a similar performance to soil.

Examples of alternative substrates are cement kiln dust and fly ash, treated auto shredder waste, construction and demolition waste, green substrate, contaminated sediment, sludge, shredded tires, MSW compost, and mechanical - biological treatment (MBT) residue. The use of these alternative substrates, separated or mixed with other substrates in the recycling process, have many environmental advantages. Moreover, the cost savings could be significant, because the landfill owner/operator would not have to purchase and import cover soil when no suitable substrate is available on-site.

This article reports the results of experiments performed in the laboratory to investigate the methane oxidation capacity of four substrates: a clayey soil, a MSW compost substrate and two MSW-clayey soil mixtures. Determining the $\mathrm{CH}_{4}$ oxidation capacity of these substrates helps to assess their potential usefulness to prevent $\mathrm{CH}_{4}$ emissions from MSW landfills to meet regulatory requirements.

\section{MATERIAL AND METHODS}

\section{Filter substrate}

The objective of this study was to identify a filter substrate with optimum conditions for methanotrophic microorganisms in the Brazilian climate. Four substrates were tested: landfill surface soil, compost of municipal solid waste (MSW) and two soil - compost mixtures.
The soil used in this experiment was collected from the surface layer of a landfill in Rio de Janeiro, Brazil. The loan area of this landfill is located in the region of Baixada Fluminense of Rio de Janeiro, in the suburb Campo Grande. In this region, the geology is quite disturbed because of the Marapicu Mendanha volcanic activity; it is a region with numerous ruptures and intrusive veins. The soil is red-yellow podzolic and has silt-clay properties.

The disposal area was used to dump MSW waste as of 1987. In 2002 it was reorganized and since 2006 , it has been used as a sanitary landfill. In 2008, 2520 tons of MSW were deposited daily.

In 2010, the MSW of Rio de Janeiro consisted of about $39.94 \%$ recyclable components (paper, plastic, glass, and metal), $55.02 \%$ organic matter and $5.04 \%$ other substrates (wood, leaves, leather, rubber, etc.), with a specific gravity of $111.15 \mathrm{~kg} \mathrm{~m}^{-3}$.

The compost of municipal solid waste was collected at a center of waste transference, recycling and composting in Rio de Janeiro City. This "Usina do Caju" has been operating since 1992 and processes about 7,000 tons of MSW from three different parts of the city (South, Center and North) per month, or about $9 \%$ of the total waste produced in these regions. Of the total amount of the waste reaching the Usina do Caju, about $15 \%$ are separated in recyclable and compostable substrates, generating about $400 \mathrm{t}$ of compost per month (Fertilurb). The non-recyclable substrate and remaining waste is transferred to the Gramacho Metropolitan Landfill. The organic compost is currently being used for the hill planting program of the city.

Soil and compost were mixed at 1:1 (w/w) and 3:1 (w/w - soil:compost) to obtain mixture 1:1 (M11) and mixture 3:1 (M31).

\section{Experimental setup}

Methane oxidation was investigated in experimental biofilters using four experimental PVC cylinders (height $60 \mathrm{~cm}$ high, internal diameter $9.9 \mathrm{~cm}$, thickness $0.67 \mathrm{~cm}$ ), with one biofilter per substrate (Figure 1). The bottom of the cylinders was filled with a $10 \mathrm{~cm}$ gravel layer to facilitate $\mathrm{CH}_{4}$ distribution, covered with a geotextile to hold the filter substrate in place and prevent gas flow clogging.

The test equipment was filled to a height of $30 \mathrm{~cm}$ with the test substrates and fed at the base with a mixture of humidified air and methane, in the desired proportions. The air was humidified in a separate pre-humidification column. The inlet methane concentration of each biofilter was maintained at $5 \mathrm{~mL} \mathrm{~min}-1$ at a feed rate of the 


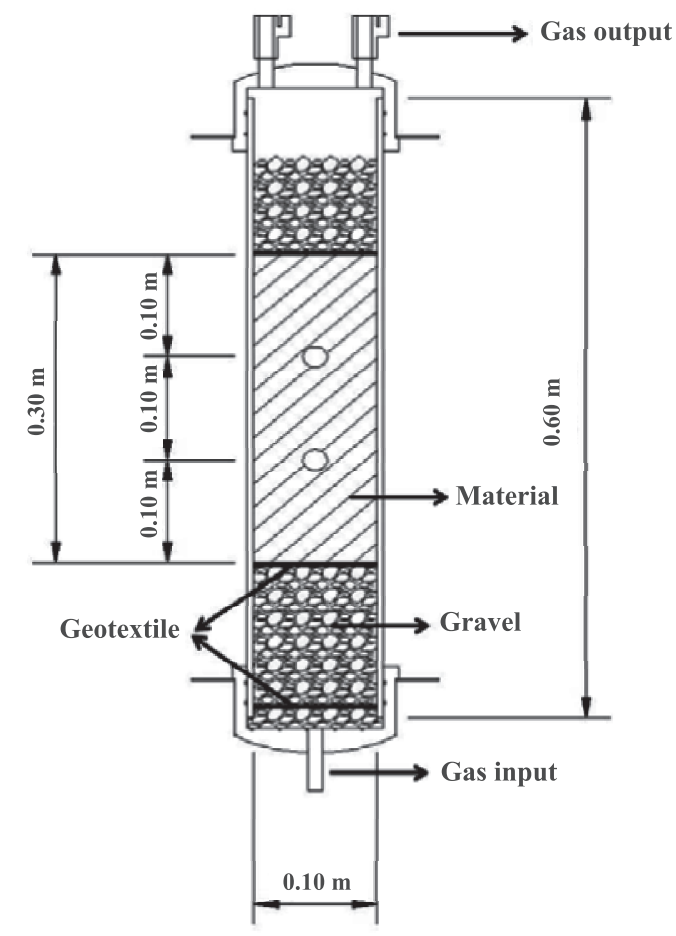

Figure 1. Diagram of the experimental setup.

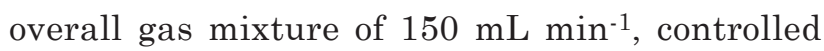
by a flow meter. This is equivalent to an empty biofilter gas retention time of $\sim 1.3 \mathrm{~h}$ (or $\sim 78 \mathrm{~min}$ ). The initial biofilter density of each substrate is shown in table 1. The $\mathrm{CH}_{4}$ concentration measured in the exhaust air and the known flow rate of the air mixture across each biofilter allowed the calculation of the $\mathrm{CH}_{4}$ emission from the surface of each substrate.

Methane, carbon dioxide and oxygen concentrations in the exhaust system were assessed by using gas chromatography three times a week. The gas concentrations $\left(\mathrm{CH}_{4}, \mathrm{O}_{2}\right.$ and $\left.\mathrm{CO}_{2}\right)$ were determined using a micro gas chromatograph (Micro-CG 3000A, Agilent) with a TCD detector and a Plot U and MolSieve 5A plot columns. The carrier gas was hydrogen. The chromatograph operating conditions are shown in table 2.

Table 1. Initial biofilter density

\begin{tabular}{cc}
\hline Substrate & Biofilter Density \\
\hline & $\times 10^{-3} \mathrm{~kg} \mathrm{~cm}^{-3}$ \\
Soil & 1.13 \\
M31 & 1.03 \\
M11 & 0.95 \\
MSW Compost & 0.74 \\
\hline
\end{tabular}

Table 2. Chromatograph operating conditions (column A = MolSieve 5A, column B = Plot $\mathrm{U}$ )

\begin{tabular}{lcc}
\hline Configuration of the GC $\mathbf{3 0 0 0}$ & Column A & Column B \\
\hline & & \\
Injector Temperature $\left({ }^{0} \mathrm{C}\right)$ & 60 & 65 \\
Column Temperature $\left({ }^{0} \mathrm{C}\right)$ & 66 & 75 \\
Column pressure (psi) & 30,00 & 15,00 \\
Post-run (psi) & 30,00 & 25,00 \\
\hline
\end{tabular}

To determine the oxidative capacity of the biofilters, the $\mathrm{CH}_{4}$ oxidation rate $\left[\mathrm{g} \mathrm{m}^{-3}\right.$ day $\left.^{-1}\right]$ and efficiency (\%) were used as analysis parameters. Oxidation rate (OR) was understood as the concentration of degraded methane multiplied by the flow gas and divided by the biofilter volume (equation 1). The efficiency (E) was defined as the concentration of degraded methane divided by the initial methane concentration (equation 2).

$$
\begin{gathered}
\text { OR }\left(\mathrm{g} \mathrm{m}^{-3} \mathrm{day}^{-1}\right)=\frac{\left(\left[\mathrm{CH}_{4}\right]_{6}-\left[\mathrm{CH}_{4}\right]_{\mathrm{s}}\right) F}{V} \\
E(\%)=\frac{\left(\left[\mathrm{CH}_{4}\right]_{6}-\left[\mathrm{CH}_{4}\right]_{\mathrm{s}}\right) F}{\left[\mathrm{CH}_{4}\right]_{6}} 100
\end{gathered}
$$

where $\left[\mathrm{CH}_{4}\right]_{\mathrm{x}}$ is the methane input (in) or output (out) concentration in the biofilter, in $\mathrm{g} \mathrm{m}^{-3}$, in the period $\mathrm{x}$ days; $\mathrm{F}$ is the biofilter gas inflow $\left(\mathrm{m}^{3}\right.$ day $\left.^{-1}\right)$ and $\mathrm{V}$ is the biofilter volume $\left(\mathrm{m}^{3}\right)$.

Samples from input and output gas were collected from each biofilter, one unit every three days, for 100 days. To saturate the biofilter and initiate the oxidative process, only methane was injected for three days, at a rate of $5 \mathrm{~mL} \mathrm{~min}^{-1}$. After this period, air was added to the methane flow, initiating the experimental measurements of the oxidative capacity of the four substrates. The new gas flow was $150 \mathrm{~mL} \mathrm{~min}{ }^{-1}$.

\section{RESULTS AND DISCUSSION}

Figure 2 shows the granulometric curves of the MSW compost and the soil used and Figure 3 shows the analysis of inert compounds present in MSW. Table 3 presents the characteristics of compost produced at the Usina do Caju.

According to the $25^{\text {th }}$ Normative Instruction (NI) (Article 1, section III and Annex III) of the Brazilian Ministry of Agriculture, Livestock and 


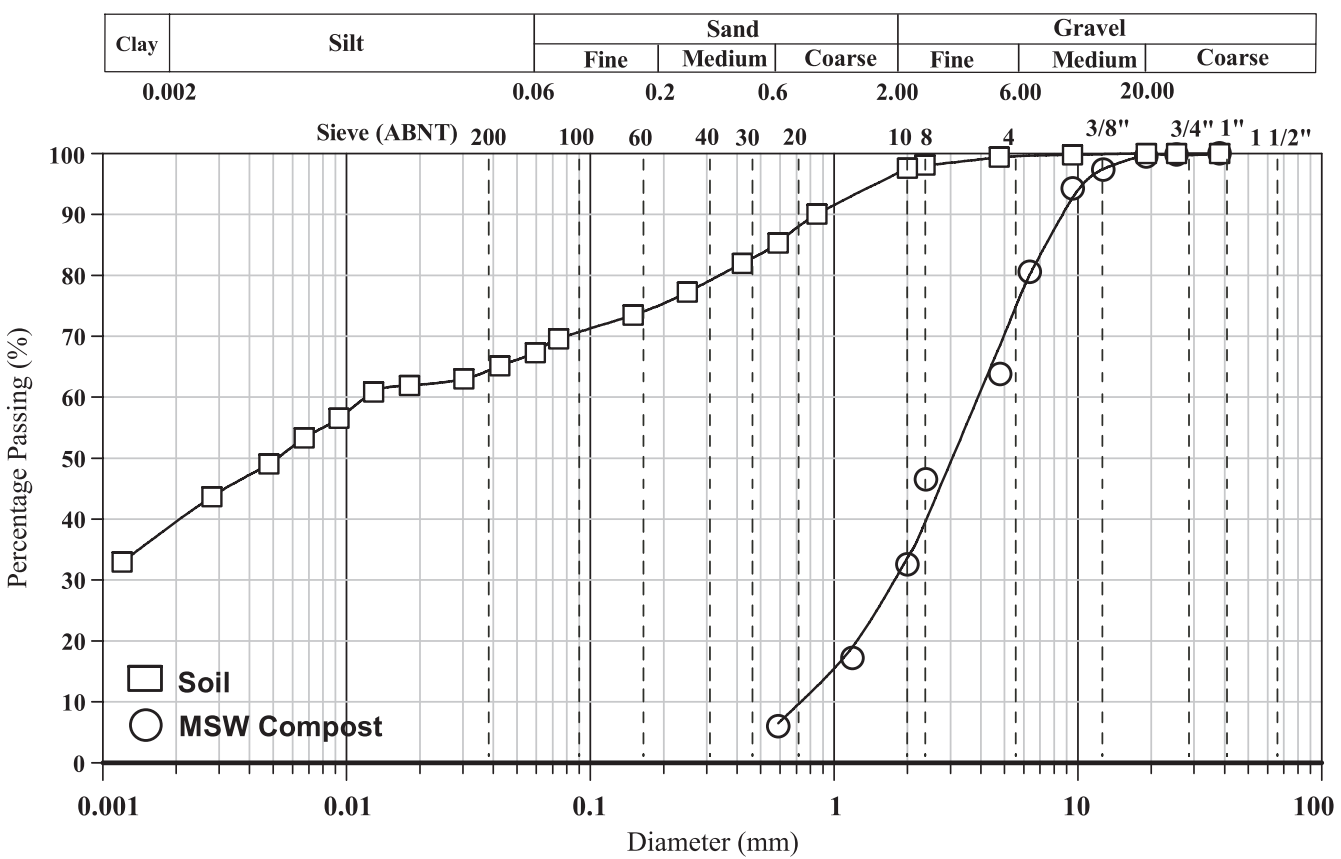

Figure 2. Granulometric analysis of MSW compost and soil.

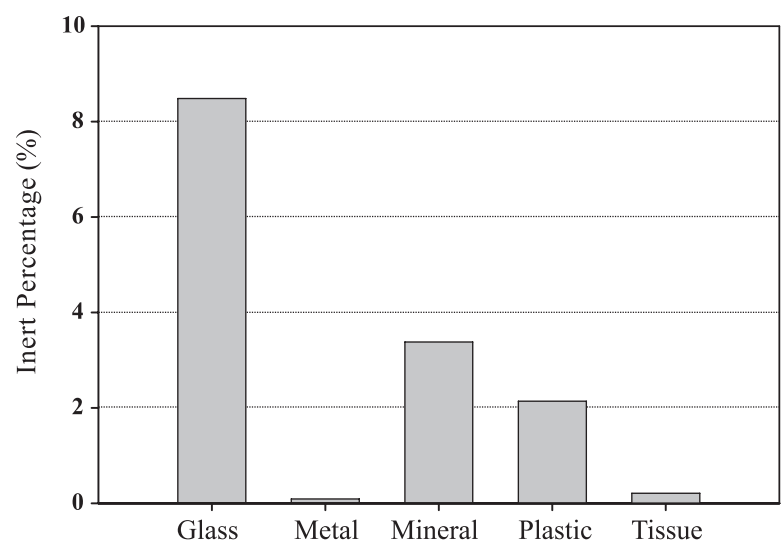

Figure 3. Gravimetric analysis of the collected MSW compost (COMLURB, 2010).
Supply (Brasil, 2009), the compost produced by COMLURB fullfilled all requirements to be used as compost fertilizer, class C.

The $\mathrm{C} / \mathrm{N}$ ratio indicates the degree of compost maturation. Although considered a mature compost, whose $\mathrm{C} / \mathrm{N}$ ratio is a maximum of $20: 1$, according to the NI number 25, Annex III , we decided to store the compost for another 35 days in the laboratory, in $200 \mathrm{~L}$ drums with perforated sides to ensure aeration of the substrate and that the composting process had been completed.

Some geotechnical properties of the four substrates used in the oxidation tests are presented in table 4.

Table 3. Chemical analysis of the MSW compost from the Usina do Caju (\% dry basis)

\begin{tabular}{lclr}
\hline \multicolumn{1}{c}{ Parameters } & \multicolumn{1}{c}{ Average $^{(\mathbf{1})}$} & Average $^{(\mathbf{1})}$ \\
\hline $\mathrm{pH}\left(\mathrm{CaCl}_{2}\right.$ 0.01 M) & 7.59 & Calcium $(\% \mathrm{CaO})$ & 10.59 \\
Specific Gravity $\left(\mathrm{kg} \mathrm{m}^{-3}\right)$ & 411.25 & Potassium $\left(\% \mathrm{~K}_{2} \mathrm{O}\right)$ & 0.42 \\
Moisture Content (\%) & 34.61 & Total Iron $\left(\mathrm{mg} \mathrm{kg}^{-1} \mathrm{Fe}\right)$ & 9641.67 \\
Total Organic Matter (\%) & 48.47 & Total Chrome $\left(\mathrm{mg} \mathrm{kg}^{-1} \mathrm{Cr}\right)$ & 77.02 \\
Total Mineral (residue - \%) & 47.50 & Total Lead $\left(\mathrm{mg} \mathrm{kg}^{-1} \mathrm{~Pb}\right)$ & 170.14 \\
Insoluble Mineral (residue - \%) & 37.63 & Zinc Total $\left(\mathrm{mg} \mathrm{kg}^{-1} \mathrm{Zn}\right)$ & 463.50 \\
Soluble Mineral (residue - \%) & 14.37 & Total Copper $\left(\mathrm{mg} \mathrm{kg}^{-1} \mathrm{Cu}\right)$ & 210.14 \\
Total Nitrogen (\%) & 5.41 & Total Sodium $\left(\mathrm{mg} \mathrm{kg}^{-1} \mathrm{Na}\right)$ & 6516.67 \\
Total Carbon (\%) $(1)$ & 72.08 & Inert (\%) & 12.22 \\
C/N Ratio & $20 / 1$ & & \\
\hline
\end{tabular}

\footnotetext{
(1) Average values obtained by COMLURB (2010).
} 
Table 4. Geotechnical properties of the biofilters. M31 $=3: 1$ soil-compost mixture and M11 = 1:1soilcompost mixture

\begin{tabular}{lcccc}
\hline \multirow{2}{*}{ Parameters } & \multicolumn{3}{c}{ Substrate } \\
\cline { 2 - 5 } & Soil & M31 & M11 & Compost \\
\hline$\rho_{\mathrm{ot}}\left(\mathrm{g} \mathrm{cm}^{-3}\right)$ & 1.57 & 1.391 & 1.208 & 0.818 \\
$\omega_{\mathrm{db}}(\%)$ & 19.6 & 22.7 & 27.5 & 39.4 \\
$\mathrm{G}_{\mathrm{s}}$ & 2.724 & 2.548 & 2.332 & 1.902 \\
$\mathrm{k}\left(\mathrm{m} \mathrm{s}^{-1}\right)$ & $5.78 \times 10^{-9}$ & $1.52 \times 10^{-10}$ & $3.41 \times 10^{-10}$ & - \\
$\mathrm{SL}$ & 63.0 & - & - & - \\
$\mathrm{PL}$ & 24.8 & - & - & - \\
$\mathrm{IP}$ & 38.2 & - & - & - \\
\hline
\end{tabular}

$\overline{\rho_{\mathrm{ot}}}:$ dry specific mass; $\omega_{\mathrm{db}}$ : water content (dry base); $\mathrm{G}_{\mathrm{s}}$ : specific gravity; $\mathrm{k}$ : hydraulic conductivity; SL: shrinkage limit; PL: plastic limit; IP: liquid limit.

The permeability of the soil and mixtures M31 and M11 was very low. Despite the comparatively higher permeability of the compost, it can still be considered low, since the permeability of sands is between $10^{-7}$ and $10^{-3} \mathrm{~m} \mathrm{~s}^{-1}$ and silts between $10^{-6}$ and $10^{-9} \mathrm{~m} \mathrm{~s}^{-1}$ (Pinto, 2002). Another noteworthy factor is the high plasticity of the soil (PI > 15).

\section{Methane oxidation rate}

The accumulated $\mathrm{CH}_{4}$ oxidation rate was plotted against time (Figure 4).

The duration of the adaptation phase is related to the feasibility of certain substrates as oxidizing environment (Figure 4). The adaptation or lag phase is defined as the time required until a stationary phase of $\mathrm{CH}_{4}$ oxidation is reached, under a given condition. The shorter the adaptation phase, the shorter is the required time until a steady state level (plateau) of $\mathrm{CH}_{4}$ oxidation is reached, so it can be inferred that the methanotrophic bacteria are more adapted at this condition. However, sometimes this adaptation phase is not observed, as described by Scheutz \& Kjeldsen (2003). In these cases, we can say that the bacteria in the medium are already adapted.

After the adaptation phase, there usually is a stationary phase. For the studied cases, this stationary phase was not observed, although it would not be true to conclude that the substrate is unsuitable as a oxidizing medium under the experimental conditions, in view of the high oxidative rates.

For the studied cases, the observed adaptation phase was as expected (Table 5).

Although an adaptation phase could be observed, none of the studied substrates reached a steady state level. However, the average recorded oxidation rates were higher than these rates for other MSW
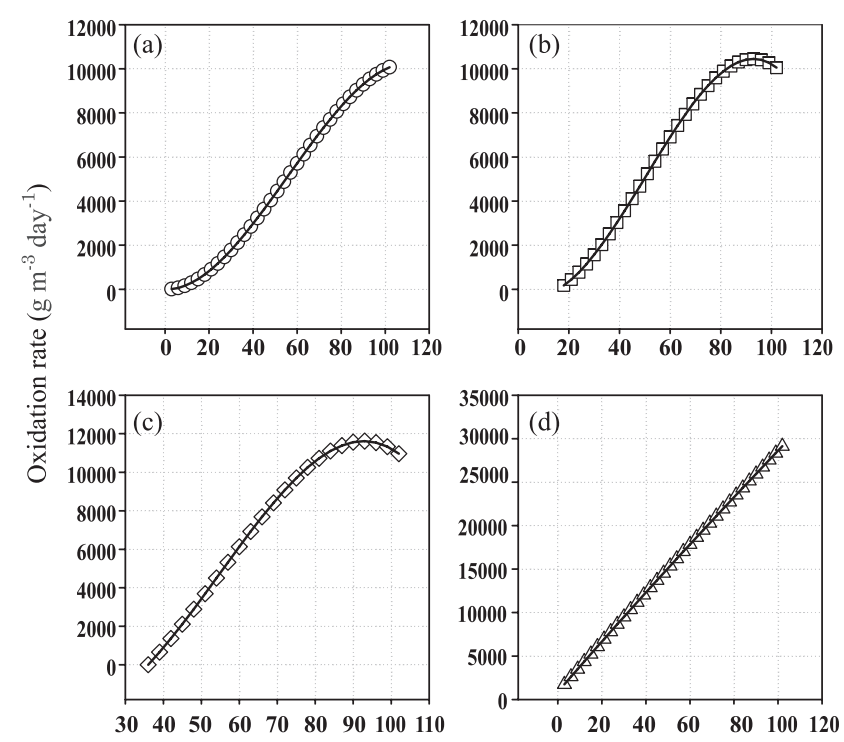

Time (day)

Figure 4. Methane oxidation rate. Biofilter substrate: (a) soil; (b) M31; (c) M11; (d) compost. M31 = 3:1 soil-compost mixture and M11 = 1:1soil-compost mixture.

compost and soil cited in the literature (De Visscher et al., 1999; Scheutz \& Kjeldsen, 2003; Streese \& Stegmann, 2003; Huber-Humer, 2004, Kettunen et al., 2006; Powelson et al., 2006). The reason for these high average oxidation rates was probably that the gas was injected at the base of the biofilters, unlike what is observed when the methane passes through the landfill cover layer towards the atmosphere, and oxygen penetrates this same layer in the opposite direction. The absolute methane oxidation rates in these tests is higher than in the studies in which gas is introduced into the top of the biofilter. This suggests that methane oxidation rates strongly depend on the laboratory test protocol. 
Table 5. Some adaptation phases reported in the literature compared with the periods observed for the four biofilters used in this work

\begin{tabular}{llr}
\hline \multicolumn{1}{c}{ Reference } & Substrate & Period (days) \\
\hline Hilger \& Humer (2003) & MSW Compost & 6 \\
Streese \& Stegmann (2003) & Garden Compost & 60 \\
Humer-Huber (2004) & MSW Compost & 6 a 10 \\
Melse \& van der Werf (2005) & Garden Compost & 15 \\
Ait- Benichou et al. (2009) & MSW Compost & 60 \\
This work & Soil & 111 \\
This work & M31 & 93 \\
This work & M11 & 93 \\
This work & MSW Compost & - \\
\hline
\end{tabular}

The beginning of the oxidative activity is variable (Figure 4). The oxidation process in the soil and MSW compost starts in the beginning of the test, while for the mixtures $\mathrm{M} 11$ and $\mathrm{M} 31, \mathrm{CH}_{4}$ oxidation was observed only about 25 days after beginning the experimental procedure. This fact could be explained by changes in the microenvironment of the methanotrophic bacteria. Bacteria in the soil and in the MSW compost were adapted to a given condition that may have changed when these two substrates were mixed, so the bacteria had to readapt to these new conditions.

However, the addition of compost to the soil is beneficial, since it induced a significant increase in the soil oxidation rate (Figure 5).

The four oxidative rates obtained were rather high (Figure 5), particularly when compared to other studies in the literature (De Visscher et al., 1999; Scheutz \& Kjeldsen, 2003; Powelson et al., 2006). However, the variation between the oxidative rates obtained and their average value is considerable. This variation may be related to the instability of the compressed air network of the laboratory.

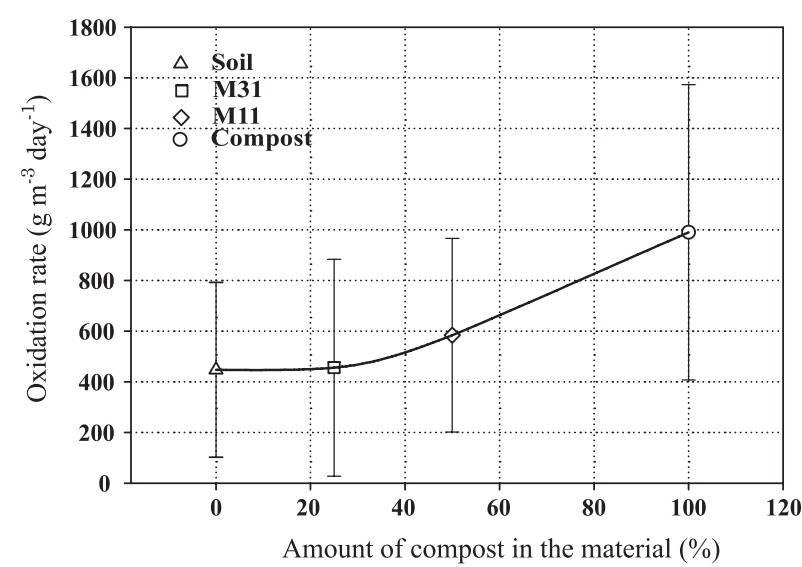

Figure 5. Average methane oxidation rate as related to the amount of compost in the sample and its standard deviation. M31 $=3: 1$ soil-compost mixture and M11 = 1:1soil-compost mixture.
However, Streese \& Stegmann (2003), who tested a mixture of organic compost (gardening), peat and of fiber (bark), also reported high oxidative rates.

\section{Biofilter efficiency}

The decrease in $\mathrm{CH}_{4}$ concentration and the increase in $\mathrm{CO}_{2}$ concentration clearly indicate ongoing biological activity, at varying efficiency. In these tests, the methane was never completely degraded, probably because of the variation in oxidation rates. However, the sinking $\mathrm{CH}_{4}$ concentration confirms the biological reaction.

The maximum $\mathrm{CH}_{4}$ oxidation efficiency was found in the range of 93-97\%, for the compost and the two mixtures. For soil, this efficiency was $67 \%$. Thus, the addition of compost to the landfill soil enhanced the $\mathrm{CH}_{4}$ oxidation efficiency.

Nevertheless, the average $\mathrm{CH}_{4}$ oxidation efficiency for all substrates was relatively low (Figure 6). Some studies show that the efficiency of a biofilter can be $100 \%$ (Huber-Humer, 2004; Berger et al., 2005; Kettunen et al., 2006), while others, e.g., Albanna et al. (2007), reported $\mathrm{CH}_{4}$ oxidation efficiency between 29 and $38 \%$, which is similar to the results found here.

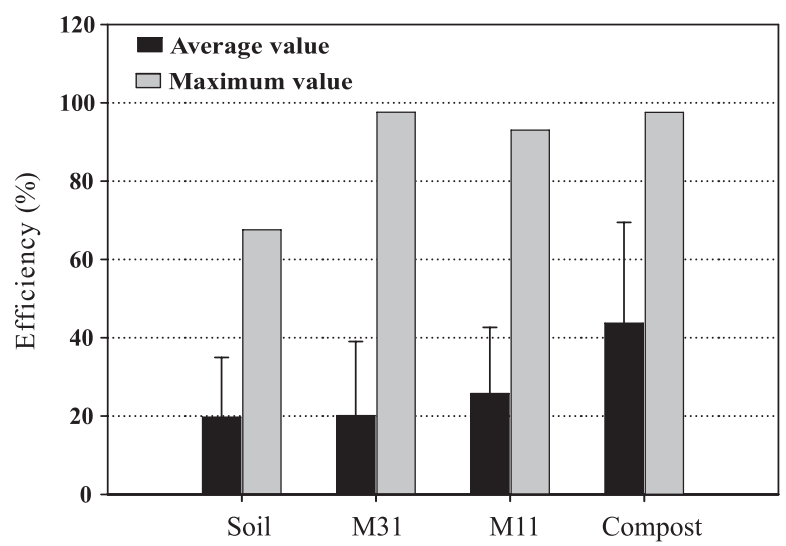

Figure 6. Biofilter efficiency versus the amount of compost in the substrate. 
An explanation for the low efficiency observed is probably the density of the compacted substrate in the biofilter. The density is, among others, related with the pore volume, ensuring a satisfactory oxygen and methane intake of the methanotrophic bacteria. Through higher-density substrates the gas will pass less easily due to the lower pore volume, preventing an appropriate air diffusion through the biofilter. The density of each substrate studied was compared to densities reported elsewhere (Figure 7).

Figure 7 shows that the dry density of all biofilter substrates was lower than of comparable data in the literature.

So, the low efficiency observed in the tests could also be explained by the short $\mathrm{CH}_{4}$ retention time by the substrates. The retention time must be sufficient to ensure that methane, with low water solubility, is converted to a form in which it becomes available to microorganisms, since they can only take up dissolved methane.

To confirm this idea, the retention times of the biofilters tested here were compared with those reported elsewhere (Kightley et al., 1995; De Visscher et al., 1999; Park et al., 2002; HuberHumer, 2004; Berger et al., 2005; Powerson et al,
2006; Kettunen et al., 2006). The retention time (RT) can be expressed as follows:

$$
R T=\frac{V}{T}
$$

where $\mathrm{V}$ is the biofilter volume $\left(\mathrm{m}^{3}\right)$ and $\mathrm{F}$ the biofilter flux $\left(\mathrm{m}^{3} \mathrm{day}^{-1}\right)$. Figure 8 shows the relationship between biofilter efficiency and retention time observed elsewhere and in this work.

It is observed that the retention times of all tested substrates were sufficient for the occurrence of oxidation, since lower retention times were reported in the literature and even then, biofilters can be highly efficient.

According to Bogner et al. (2005) Abichou et al. (2006) and Stern et al. (2007), thicker biofilters with greater moisture-holding capacity retain $\mathrm{CH}^{4}$ for a longer time. This increased retention time of $\mathrm{CH}_{4}$ in the biofilter allows a higher fraction to be oxidized. On the other hand, a greater inlet flow reduces the retention time and thereby oxidation. Huber-Humer \& Lechner (1999) argued that pore volume, water content and pore arrangement play a decisive role in gas retention in the substrate,
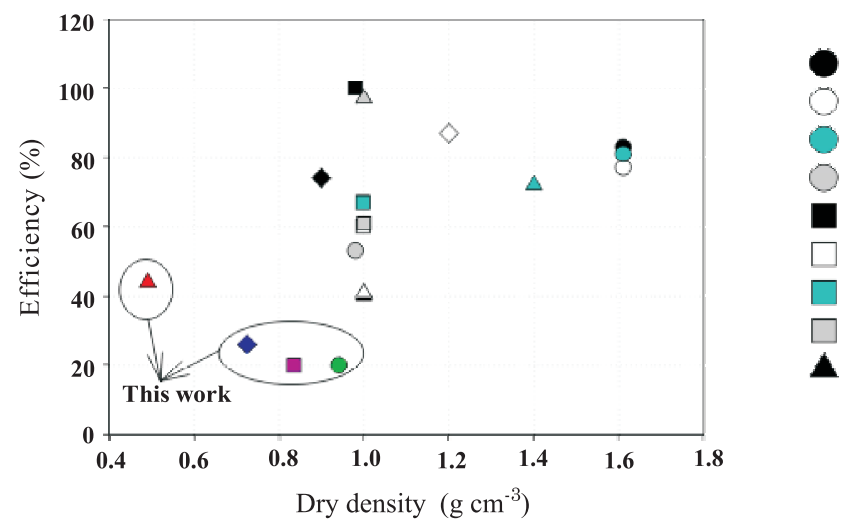

Park et al. (2002)

Park et al. (2002)

Park et al. (2002)

Huber-Humer (2004)

Huber-Humer (2004)

De Visscher et al. (1999)

De Visscher et al. (1999)

Kightley et al. (1995)

Kightley et al. (1995)

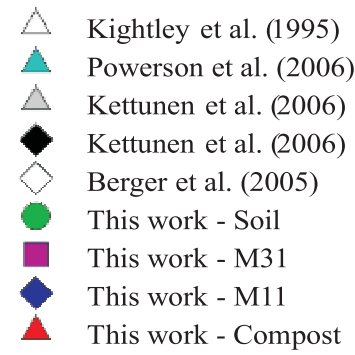

Figure 7. Biofilter efficiency versus dry density, as reported in the literature and this study.

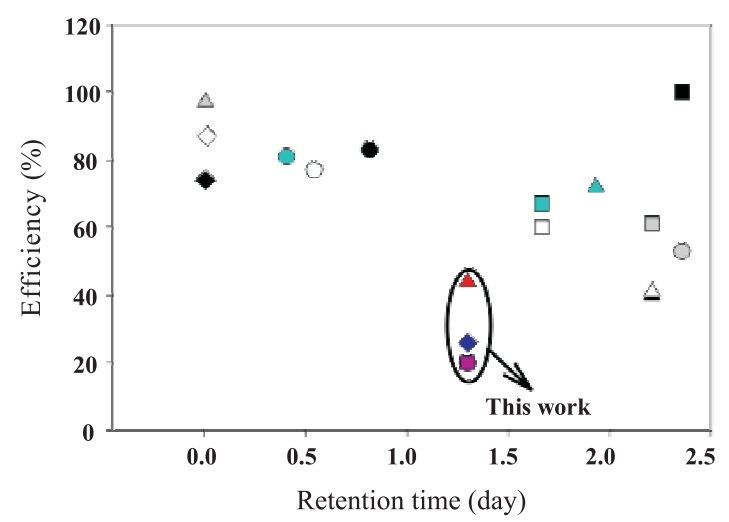

- Park et al. (2002)

Park et al. (2002)

Park et al. (2002)

Huber-Humer (2004)

- Huber-Humer (2004)

$\square$ De Visscher et al. (1999)

$\square$ De Visscher et al. (1999)

$\square$ Kightley et al. (1995)

- Kightley et al. (1995)
A Kightley et al. (1995)

$\therefore$ Powerson et al. (2006)

$\triangle$ Kettunen et al. (2006)

- Kettunen et al. (2006)

Berger et al. (2005)

- This work - Soil

- This work - M31

- This work - M11

$\Delta$ This work - Compost

Figure 8. Biofilter efficiency versus retention time, as reported in the literature and in this study. 
consequently influencing the methane oxidation rate and efficiency.

\section{CONCLUSIONS}

1. One hundred days after the beginning of the experiment, the soil biofilter showed an average methane oxidation rate of $447.21 \mathrm{~g} \mathrm{~m}^{-3}$ day $^{-1}$, i.e., a removal efficiency of $19.74 \%$. The two soil-compost mixtures showed average methane oxidation rates of $455.73-583.98 \mathrm{~g} \mathrm{~m}^{-3} \mathrm{day}^{-1}$, corresponding to a removal efficiency of $20.12-25.78 \%$. The $\mathrm{CH}_{4}$ oxidation capacity of the 1:1 mixture (M11) was better than of the 3:1 mixture (M31), indicating that the amount of compost has a strong influence on the $\mathrm{CH}_{4}$ oxidation capacity of soil-compost mixtures. The $\mathrm{CH}_{4}$ oxidation rate was highest in the MSW compost biofilter, on average $990.44 \mathrm{~g} \mathrm{~m}^{-3}$ day $^{-1}$, corresponding to an efficiency of $43.72 \%$ and with a peak rate of $2,010.17 \mathrm{~g} \mathrm{~m}^{-3}$ day $^{-1}$ and efficiency of $97.57 \%$.

2. Fugitive emissions from all landfills and total emissions from older and smaller landfills without gas collection systems could be minimized by methanotrophic bacteria in soil layers and biofilters.

3. Based on the above results, the use of compost in a properly managed biofilter should be capable of greater reductions in atmospheric $\mathrm{CH}_{4}$ emissions compared to soil-compost mixtures or soil only.

4. The disadvantage of using MSW compost is the low density, so high volumes of this substrate are required to cover large areas with appropriate compaction. Mixed with soil, the distribution and compaction of the cover substrate is easier. Thus, although the compost alone is more efficient in methane oxidation than the mixtures, it is suggested to use a soil-compost mixtures in landfills, due to their operational advantages.

\section{ACKNOWLEDGEMENTS}

We thank CNPq, CAPES and FAPERJ for the financial support, and Natalia P. Caninas and Ricardo Sena for the MSW information and for providing compost from the Caju Plant.

\section{LITERATURE CITED}

ABICHOU, T.; CHANTON, J.; POWELSON, D.; FLEIGER, J.; ESCORIAZA, S.; LEI Y. \& STERN, J. Methane flux and oxidation at two types of intermediate landfill covers. Waste Manag., 26:1305-1312, 2007.
ALBANNA, M.; FERNANDES, N. \& WARITH, M. Methane oxidation in landfill cover soil; the combined effects of moisture content, nutrient addition, and cover thickness. J. Environ. Eng. Sci., 6:191-200, 2007.

AIT-BENICHOU, S.; JUGNIA, L.B.; GREER, C.W. \& CABRAL, A.R. Methanotrophs and Methanotrophic Activity in Engineered Landfill Biocovers. Waste Manag., 29:25092517, 2009 .

BERGER, J.; FORNÉS, L.V.; OTT, C.; JAGER, J.; WAWRA, B. \& ZANKE, U. Methane oxidation in a landfill cover with capillary barrier. Waste Manag., 25:369-373, 2005.

BOECKX, P.; van CLEEMPUT, O. \& VILLARALVO, I. Methane emission from a landfill and the methane oxidizing capacity of its covering soil. Soil Biol. Biochem., 8:1397-1405, 1996.

BRASIL. Ministério da Agricultura, Pecuária e Abastecimento. NI - Brasilian Normative Instruction. $\mathrm{n}^{\circ} 25$, de 23 de julho de 2009. Normas sobre as especificações e as garantias, as tolerâncias, o registro, a embalagem e a rotulagem dos fertilizantes orgânicos simples, mistos, compostos, organominerais e biofertilizantes destinados à agricultura. Ministério da Agricultura, Pecuária e Abastecimento. (in Portuguese)

BOGNER, J.; SPOKAS, K.; CHANTON, J.; POWELSON, D.; FLEIGER, J. \& ABICHOU, T. Modeling landfill methane emissions from biocovers: A combined theoretical-empirical approach. In: INTERNATIONAL WASTE MANAGEMENT AND LANDFILL SYMPOSIUM, 10., Margherita di Pula, 2005. Anais... Cagliari, Italy CISA Environmental Sanitary Engineering Centre, 2005. CD ROM.

COMLURB - Companhia Municipal de Limpeza Urbana da Cidade do Rio de Janeiro. Comunicação pessoal. 2010.

DE VISSCHER, A.; THOMAS, D.; BOECKX, P. \& van CLEEMPUT, O. Methane oxidation in simulated landfill cover soil environments. Environ. Sci. Technol., 33:18541859, 1999.

HANSON, R.S. \& HANSON, T.E. Methanotrophic bacteria. Microbiol. Rev., 60:439-471, 1996.

HILGER, H.A. \& HUMER, M. Biotic landfill cover treatments for mitigating methane emissions. Environ. Monitor. Assess, 84:71-84, 2003.

HUBER-HUMER, M. Abatement of landfill methane emissions by microbial oxidation in biocovers made of compost. Viena, Austria, University of Natural Resources and Applied Life Sciences, 2004. 377p. (Tese de Doutorado)

HUBER-HUMER, M. \& LECHNER, P. Alternative approach to the elimination of greenhouse gases from old landfills. Waste Manag. Res., 17:443-452, 1999.

KETTUNEN, R.; EINOLA, J.K.M. \& RINTALA J. Landfill methane oxidation in engineered soil columns at low temperature. Water Air Soil Pollut., 177:313-334, 2006.

KIGHTLEY, D.; NEDWELL, D.B.A. \& COOPER, M. Capacity for methane oxidation in landfill cover soils measured in laboratory-scale soil microcosms. Appl. Environ. Microbiol., 61:592-601, 1995. 
MELSE, R.W. \& van der WERF, A.W. Biofiltration for mitigation of methane emission from animal husbandry. Environ. Sci. Technol., 39:5460-5468, 2005.

PARK, S.; BROWN, K.W. \& THOMAS, J.C. The effects of various environmental and design parameters on methane oxidation in a model biofilter. Waste Manag. Res., 20:434$444,2002$.

PINTO, C.S. Curso básico de mecânica dos solos em 16 aulas. 2.ed. São Paulo, Oficina de Textos, 2002. 355p.

POWELSON, D.K.; CHANTON, J.; ABICHOU, T. \& MORALES, J. Methane oxidation in water-spreading and compost biofilters. Waste Manag. Res., 24:528-536, 2006.

SCHEUTZ, C. \& KJELDSEN, P. Capacity for biodegredation of cfcs and hcfcs in a methane oxidative counter-gradient laboratory system simulating landfill soil covers. Environ. Sci. Technol., 37:5143-5149, 2003.
STERN, J.C.; CHANTON, J.; ABICHOU, T.; POWELSON, D.; YUAN L.; ESCORIZA, S. \& BOGNER, J. Use of a biologically active cover to reduce landfill methane emissions and enhance methane oxidation. Waste Manag., 27:1248-1258, 2007.

STREESE, J. \& STEGMANN, R. Microbial oxidation of methane from old landfills in biofilters. Waste Manag., 23:573-580, 2003.

WHALEN, S.C.; REEBURGH, W.S. \& SANDBECK, K.A. Rapid methane oxidation in a landfill cover soil. Appl. Environ. Microbiol., 56:3405-3411, 1990. 